\title{
Effect of training provided on knowledge and attitude of reproductive health among adolescent students in Asmara, Eritrea, a quasi-experimental study
}

Ariam Woldu ( $\nabla$ ariamwoldu21@gmail.com )

Orotta College of Medicine and Health Sciences, Asmara, Eritrea

Lidia Ghirmai

Orotta College of Medicine and Health Sciences, Asmara, Eritrea

Eyasu $\mathrm{H}$. Tesfamariam

College of Science, Mainefhi, Eritrea.

Ghidey Gebreyohannes

Orotta College of Medicine and Health Sciences, Asmara, Eritrea

\section{Research Article}

Keywords: Adolescent females, Knowledge, Attitude, Reproductive health and emergency contraceptives

Posted Date: March 3rd, 2022

DOI: https://doi.org/10.21203/rs.3.rs-1402821/v1

License: (c) (i) This work is licensed under a Creative Commons Attribution 4.0 International License.

Read Full License 


\section{Abstract}

Background: The period of adolescence that is between 10 and 19 years of age is the time which largely shapes the future life of boys and girls. Adolescent girls are more likely to experiment sexual practice before they have knowledge of its subsequent consequences.

Objective: This study aimed to assess the effect of training on the knowledge and attitude of female adolescent students towards reproductive health and emergency contraceptives.

Methods: A school based single group pre-post quasi-experimental study design was employed in four secondary schools in Asmara on 140 female students. Trained data collectors during the pre-test, immediate post-test and three months later used a predesigned and pretested questionnaire to collect data regarding the knowledge and attitude via interview. Repeated measures ANOVA was used to make comparisons in knowledge and attitude scores using SPSS (Version 22).

Results: Of all the study participants, a quarter (30.0 \%) have heard of the methods of emergency contraceptives at the initial assessment. After training, three quarter $(75.7 \%)$ of the students were able to have the correct knowledge. Life skill teachers at the school (57.9\%) were mentioned as the primary source of information regarding reproductive health. The health education provided to adolescent females resulted in a significant increase on the mean scores of their knowledge from $6.57 / 13(S D=2.08)$ pre intervention to $9.26 / 13(S D=2.14)$ immediate post intervention. However, the score declined significantly $(p<0.001)$ from immediate after intervention to 3 months' follow-up by 0.80 . Although the score declined, knowledge at 3 months' follow-up was still significantly greater than that of preintervention $(p<0.0001)$. The percentage of participants who believe a girl should carry emergency contraceptives in her bag significantly improved from $52.3 \%$ to $86.2 \%$ after intervention. The mean (SD) scores of attitude towards reproductive health significantly increased at three time periods. Mean (SD) scores at time 1 (pre-intervention), time 2 (immediate post) and time 3 (three-month follow-up) were 48.98 (4.68), 51.03 (4.04), and 49.65 (4.01) out of 69 respectively. Attitude score was significantly higher at immediate post intervention than pre-intervention $(p<0.001)$ and immediate post intervention than 3 months' follow-up ( $p=0.001$ ), but no significant difference existed between 3 months' follow-up and preintervention $(p=0.395)$.

Conclusion: This research has yielded a valuable evidence that educational intervention can bring a significant increase in the knowledge and in introducing positive attitude towards reproductive health and usage of emergency contraceptives among adolescents. Reproductive health education with special emphasis on contraceptives should be part of the structured school curriculum to reach all students in the country with schools playing a leading role in coordinating the efforts of awareness creation.

\section{Background}

Adolescents make up twenty percent of the global population and the present generation of adolescents happens to be the largest in history. Thanks to the high fertility rates in low-and-middle income countries, 
nearly $90 \%$ of the adolescents constituting a far greater proportion of the total population live there [1]. This fact also applies to Eritrea where $25.5 \%$ of its population is made up of adolescents [2]. Given their young age, it is not unusual for one to expect them to be healthy, yet risky behaviours result in premature death from many causes including unwanted pregnancy followed by unsafe abortion, motor vehicle crashes, suicide, drug overdose, and violence [3].

Unwanted pregnancy among adolescents occurs because girls and boys become sexually active before they are aware of the need for contraception. Studies indicate that pregnancy at the age from 15-19 is 23-236 per 1,000 in Africa, as compared to 54-153 per 1,000 in Latin America and only 30 per 1,000 in the developed countries [4]. In a 2017 study by the National Union of Eritrean Women (NUEW), it was reflected that one of the major driving factors for early marriage is unplanned pregnancy among young girls. All participants from the study expressed their concerns that early unsafe sexual practice is very rampant in the country and needs urgent action [5]. According to another study done in Eritrea, early sexual practice was found to be widespread among junior and secondary school students [6]. A survey done in 2010 on population and health of Eritrea [7] also showed that men and women have poor knowledge of reproductive health $(\mathrm{RH})$ which could be ascribed to the early unsafe sexual practices. The same survey showed that only $12 \%$ of men and $17 \%$ of women knew the days of ovulation, $65 \%$ have never been exposed to any family planning information, $66 \%$ lack knowledge on sexually transmitted diseases (STDs). According to the same source, only $4 \%$ of women of child-bearing age were users of family planning, of sexually active unmarried women $11 \%$ had knowledge about emergency contraceptive (EC), and none of them had ever used it.

In Sub Saharan Africa, adolescent females make decisions about engaging in sex without having accurate information, access to support and health care services. Adolescents are not aware of what to do after unprotected sexual intercourse in order to avoid pregnancy [8]. Most of the time, young girls do not use even the available health services due to fear of social stigma and lack of knowledge [9-11]

Pregnancy at adolescence is believed to lead to maternal and new born complications, economic dependency and psychological problem. If pregnancy continues while in school, the girl is forced to drop out of school that may define her future. On the other hand, if the pregnancy is terminated illegally, it may be followed by unsafe and unsuccessful abortion and their risk of very serious morbidity and mortality. In Eritrea, of pregnancy related mortality, $40 \%$ are attributed to unsafe abortion [12]. This is supported by other sources, indicating that abortion and its complication is the second leading cause of death in Eritrea, and it is assumed sepsis is exacerbated by unsafe abortion initiated outside the health facility [13, 14]. Young girls who get pregnant also end up in unplanned and forced marriages, which puts her in a vicious cycle of poverty. This being the effect, the cause behind it is unprotected sexual intercourse [11].

Unplanned and unprotected sexual intercourse has an emergency nature that requires immediate action to prevent pregnancy. EC are methods to prevent pregnancy after unprotected sexual intercourse. The importance of ECs in preventing pregnancy that occurs after unprotected intercourse among adolescent females is attracting higher interest among researchers and government policy makers. Thus, using EC 
after unprotected intercourse to avoid pregnancy at adolescence is a method that contributes to reduced maternal mortality [15].

The problem that comes in between the effect and cause of any intervention that is proposed to tackle all the problems is the lack of adequate knowledge about $\mathrm{RH}$ specifically the existence and benefit of EC [10]. It is for this basic reason that intervention to test the efficacy of training was conducted in this study. To the best of the researcher's knowledge, this is the first study to evaluate the effect of a school-based educational intervention on the knowledge and attitude of adolescent girls in Eritrea towards RH.

Intervention is believed to be significant in many aspects of changing the knowledge and attitude of adolescents towards $\mathrm{RH}$. The intervention through training proposed in this study is expected to fill the gap in existing empirical studies on the field. Moreover, the results obtained from this study can be replicated in schools of the whole nation to educate students and mitigate the problem. On a bigger umbrella, considering integrating a well prepared $\mathrm{RH}$ training in the curriculum of secondary schools can enable students to have an easier and better understanding of their RH. The effectiveness of an educational intervention depends on an appropriate application of behavioural science theories. This research thus employed the Theory of Planned Behaviour-based educational intervention. This theory assumes that attitude, subjective norms, and perceived behavioural control lead to the development of a behavioural intention and the intention is the immediate antecedent of behaviour [16].

\section{Method}

\section{Study design and setting}

The design used in this study was quasi experimental in which a cohort of students was assessed at three time points (pre-intervention, immediate after intervention, and 3-months later). The study was performed in a quantitative approach. It was conducted in Asmara (the capital of Eritrea), from August 2019 to November 2019.

\section{Study population}

All female secondary school students in grades 9 and 10 in Asmara constituted the study population. As per the report of Ministry of Education of Central Region of Eritrea in 2018, the total number of female secondary school students was 6779 . The list of secondary schools and their respective number of students are shown in Table 1 [17]. 
Table 1

Secondary schools in Asmara, their location and their respective number of students $(n=130)$.

\begin{tabular}{|c|c|c|c|c|}
\hline \multirow[t]{2}{*}{ Sub zone } & & \multicolumn{2}{|c|}{ Number of Students } & \multirow[t]{2}{*}{ Total } \\
\hline & & Grade Nine & Grade Ten & \\
\hline \multicolumn{5}{|c|}{ South West } \\
\hline & KeihBahri & 484 & 463 & 947 \\
\hline & Sembel & 297 & 265 & 562 \\
\hline & Barka & 370 & 399 & 769 \\
\hline \multicolumn{5}{|c|}{ South East } \\
\hline & Halay & 428 & 444 & 872 \\
\hline & Sematat & 402 & 297 & 699 \\
\hline & Limeat & 217 & 212 & 429 \\
\hline \multicolumn{5}{|c|}{ North West } \\
\hline & Asmara Hafeshawi & 450 & 360 & 810 \\
\hline & Harnet & 329 & 318 & 647 \\
\hline \multicolumn{5}{|c|}{ North East } \\
\hline & IssakTeweldemedhin & 278 & 281 & 559 \\
\hline & Adulis & 245 & 240 & 485 \\
\hline Total & & 3500 & 3279 & 6779 \\
\hline
\end{tabular}

\section{Source: Ministry of Education, Office for the Central Region (2018)}

\section{Sampling Technique}

In order to make the samples representative, students were selected using two stage stratified cluster sampling. During the first stage of sampling, one school from each subzone was selected, totalling to four schools. Then, proportional sample of students were randomly selected from the four schools during the second stage of sampling.

\section{Sample Size}

Sample size was calculated using G-power software considering the parameters: effect size $=0.20$, type I error $=0.05$, power $=0.90$, number of repeated measures $=3$, correlation among the repeated measures $=$ 
0.5 , and non-sphericity correction $=0.55$. Initially, the sample size was computed to be 84 . However, sampling technique adjustment was made for two stage stratified cluster sampling, by multiplying the obtained sample size by the design effect (Deft $=1.5$ ). Hence, the sampling technique adjusted sample size became 126 . Finally, after accounting, $10 \%$ expected non-responses or missing students, the sample size was found to be 140 .

\section{Data Collection tools and methods}

The researcher developed a questionnaire from documents compiled by WHO (UNDP/ UNFPA/ WHO/ World Bank [18]; which further was revised for its relevance by local health experts. The questionnaire was constructed using both closed and open-ended questions. The questionnaire was originally in English but for an easiness of understanding, it was translated to Tigrigna with the help of linguists. The translated Tigrigna version was back-translated to English to look on potential discrepancies and then amendments were made accordingly. Before applying it in the main study, it was pre-tested in a school that was not part of the sampled ones. The questionnaire captured the following information: personal and family characteristics data of students, knowledge on $\mathrm{RH}$, and attitude of students towards $\mathrm{RH}$. Data was collected using self-administered questionnaire.

\section{Data collection procedure}

Phase I of the data collection from the adolescents (baseline assessment) using a questionnaire immediately before receiving training took place from July 31 st to August 9th. Immediate post education evaluation of adolescents was done by the same questionnaire used to assess the students in the pretest. Phase II or post intervention data collection was done after the student was appointed for 3 months after the training session and this took place from October 31 st to November 5. Recruitment of participants, intervention and data collection was all done in the schools.

\section{Validity}

The face and content validity of the data collection instruments was ensured as the tool was reviewed by $\mathrm{RH}$ experts from the $\mathrm{MOH}$, clinical nurses and advisors from the college. Considering their suggestions and recommendations, the tool was modified and finalized to fit the local context.

\section{Reliability}

The data collectors were given strict guidance on how to fill the knowledge and attitude questionnaires and observe the participants to avoid the inter-rater biases.

\section{The intervention and its procedure}

A manual for the educational training was prepared by the researcher in reference to midwifery text books and documents [19-23]. The manual was edited by the midwifery experts (Ph.D) at the college and approved by the ethical and scientific committee along with the proposal. Besides, a brochure containing the most important points that students need to remember was developed. The contents of the manual 
include: (i) male and female reproductive system and developmental changes during adolescence, (ii) adolescent pregnancy, and (iii) emergency contraception.

The primary investigator of the research gave a two days training to two midwife educators on how to use a learner centred teaching and both taught all students by sharing topics to prevent any discrepancy. Prior to data collection, all the schools were visited for preliminary assessments. Then, based on the information obtained, decisions were made regarding selection of the schools and students. After selecting the schools and the students, dates for orientation and data collection were set, upon discussing with the directors of the four schools. On a convenient time suggested by the school director, the objective of the study was explained to the selected students. Before the educational intervention, a one-day orientation on how to fill in the questionnaire was given to the selected students. Any queries on the questionnaire were discussed to get common understanding. Later on, students took the pre-test. Next, training was given for fourteen days, two hours a day, using flipchart, overhead projectors and video clips after giving one training manual and the brochure for each student. Then, ground was given to the students for a participatory discussion to make them aware of $\mathrm{RH}$ and consequences of unprotected sex. After one hour of the completion of the discussions, the immediate after intervention test was conducted. In order to assess, the retention of the students on what exactly they have learned, they were politely enquired to appear after three months. Data after three months for the same students was also finally collected. The data collection tool used at the three time periods was the same.

\section{Study outcomes and measures}

The dependent variables in this study were knowledge, and attitude towards $\mathrm{RH}$ at pre-intervention, immediately after, and 3 months later. The intervention made was an educational training regarding $\mathrm{RH}$.

Knowledge regarding $\mathrm{RH}$ consisted 13 items, resulting to a minimum of 0 and a maximum of 13 scores. The higher the score the more knowledge she had.

Attitude towards RH was captured using 3-point Likert scale ( 1 = disagree, 2 = moderate, 3 = agree). It consisted 23 items, resulting to a minimum and maximum scores of 23 and 69 respectively. The higher the score the more positive attitude she had.

\section{Data Analysis}

Data was coded, edited and entered, cleaned for inconsistencies, and analysed using Statistical Package for Social Sciences (SPSS, Version 23) software. Frequency (percentage) was used to describe categorical variables, while mean (SD), and median (IQR) were used to summarize the continuous ones, as appropriate. Scores of the items that were constructed to measure the knowledge and attitude towards $\mathrm{RH}$ were assessed using Kolmogorov-Smirnov test to decide on whether to use parametric or nonparametric test. After confirmation of normality, the effect of intervention through time on knowledge regarding $\mathrm{RH}$ was assessed using repeated measures ANOVA. Pair wise comparison was performed using Bonferroni post hoc multiple tests adjustment. 95\% $\mathrm{Cl}$ intervals were computed for the mean measure scores computed. Finally, mixed between-within ANOVA was conducted to assess the impact of 
educational intervention on knowledge about $\mathrm{RH}$ across categories of background characteristics. On the other hand, effect of intervention through time of attitude towards $\mathrm{RH}$ was conducted using repeated measures ANOVA followed by Bonferroni post hoc pair wise comparisons. Finally, mixed between-within ANOVA was conducted to assess the impact of educational intervention on attitude towards $\mathrm{RH}$ across categories of background characteristics. $P$-values less than 0.05 were rendered as significant in all analyses except for that of Box M $(p<0.001)$.

\section{Results}

A total of 154 students were approached to participate in the study according to the eligibility criteria. Fourteen were excluded as they did not consent to be part of the study so 140 were enrolled in the study and all were successfully followed to the immediate interview. Ten students lost to follow up and 130 completed the assessment at the three months' time making them the final participants for the study whose data is taken for analysis. Hence, the response rate was $92.9 \%$. A Consolidated Standards of Reporting Trials flow chart showing subjects initially enrolled, intervened, followed up and included in the analyses in the quasi- experimental study is attached as supporting information (online supplemental material S2).

\section{Personal and Family Characteristics}

Table 2 shows the personal and family characteristics of the study participants. The minimum and maximum ages of the students were 14 and 18 years respectively, with a mean age of $15.36(\mathrm{SD}=1.02)$ years. The majority of the participants were orthodox (77.9\%) and $7.9 \%$ were Catholic and Muslims each, and $2.1 \%$ were protestant. The percentage of students who live with their parents, mother only, father only, and others were $75.7 \%, 20 \%, 1.4 \%$, and $2.9 \%$ respectively. Only $30 \%$ and $21.4 \%$ of the students always discuss sex-related issues with their mothers and fathers respectively, while $12.9 \%$, and $36.4 \%$ respectively never discuss with their mother and father. The majority $(67.1 \%)$ of the study participants had elder sisters, and $60 \%$ of them had elder brothers. Academic background of the students' fathers, and mothers showed that $6.4 \%$ of fathers and $11.4 \%$ of mothers were illiterate, $13.6 \%$ of fathers and $29.3 \%$ of mothers were at elementary level, $28.6 \%$ of fathers, and $29.3 \%$ of mothers were at secondary level, and $46.4 \%$ of fathers and $30 \%$ of mothers were at post-secondary level of education. About $23 \%$ of them were not living with both biological parents. 
Table 2

Personal and family characteristics of the study participants from secondary schools in Asmara, Eritrea, August to November $2019(n=130)$.

\begin{tabular}{|c|c|c|c|}
\hline Variable name & Response Type & Number & Percentage \\
\hline \multicolumn{4}{|c|}{ Age $($ Mean $=15.35, S D=1.025)$} \\
\hline & $13-15$ & 82 & 63.1 \\
\hline & $16-18$ & 48 & 36.9 \\
\hline \multicolumn{4}{|l|}{ Religion } \\
\hline & Orthodox & 100 & 76.8 \\
\hline & Catholic & 11 & 8.5 \\
\hline & Moslem & 8 & 6.2 \\
\hline & Protestant & 11 & 8.5 \\
\hline \multicolumn{4}{|c|}{ With whom she lives } \\
\hline & Parents & 98 & 75.4 \\
\hline & Mother only & 26 & 20.0 \\
\hline & Father only & 2 & 1.5 \\
\hline & Other & 4 & 3.1 \\
\hline \multicolumn{4}{|c|}{ Discuss sex issues with Father } \\
\hline & Always & 29 & 22.3 \\
\hline & Frequently & 9 & 6.9 \\
\hline & Sometime & 36 & 27.7 \\
\hline & Rarely & 8 & 6.2 \\
\hline & Never & 48 & 36.9 \\
\hline \multicolumn{4}{|c|}{ Discuss sex issues with Mother } \\
\hline & Always & 38 & 29.2 \\
\hline & Frequently & 15 & 11.5 \\
\hline & Sometime & 54 & 41.5 \\
\hline & Rarely & 6 & 4.6 \\
\hline & Never & 17 & 13.1 \\
\hline
\end{tabular}




\begin{tabular}{|c|c|c|c|}
\hline Variable name & Response Type & Number & Percentage \\
\hline & Yes & 86 & 66.2 \\
\hline & No & 44 & 33.8 \\
\hline \multicolumn{4}{|c|}{ Presence of elder brother } \\
\hline & Yes & 77 & 59.2 \\
\hline & No & 53 & 40.8 \\
\hline \multicolumn{4}{|c|}{ Have you ever gone to clubs } \\
\hline & Yes & 9 & 6.9 \\
\hline & No & 121 & 93.1 \\
\hline \multicolumn{4}{|c|}{ Difference in academic performance } \\
\hline & Better & 65 & 50.0 \\
\hline & Less & 20 & 15.4 \\
\hline & No change & 45 & 34.6 \\
\hline \multicolumn{4}{|c|}{ Educational level of father } \\
\hline & Illiterate & 8 & 6.2 \\
\hline & Elementary & 25 & 19.2 \\
\hline & Secondary & 38 & 29.2 \\
\hline & Post high school & 59 & 45.4 \\
\hline \multicolumn{4}{|c|}{ Educational level of mother } \\
\hline & Illiterate & 15 & 11.5 \\
\hline & Elementary & 37 & 28.5 \\
\hline & Secondary & 40 & 30.8 \\
\hline & Post high school & 38 & 29.2 \\
\hline
\end{tabular}

\section{Source of Knowledge on RH}

The responses on the source of information regarding $\mathrm{RH}$ showed that the majority were life skill teachers at the school (57.9\%). More than one fourth (27.9\%) of the students also responded that they get information from their mothers, while $17.9 \%$ and $15.9 \%$ said from their friends and sisters respectively (Fig. 2).

\section{Knowledge on RH}


Out of the 13 items that assessed knowledge regarding $\mathrm{RH}, 11$ items were correctly known by less than half of the students at pre-intervention (Table 3). The remaining two items: a girl stops growing after she makes sexual intercourse (80.0\%), and EC should be taken with the consultation of a health care provider (66.2\%); were correctly known by more than half of the students at pre-intervention. The item 'when is EC taken?' was the least (5.4\%) correctly known, followed by the correct time at which a woman gets pregnant within the menstrual cycle (18.5\%) before the intervention.

However, at immediate post, all the 13 items were correctly responded by more than $60 \%$ of the students. At immediate post, usage of emergency contraceptive after every sexual intercourse (58.5\%) was the least correctly known followed by "selection of the suitable EC" (61.5\%).

Moreover, the percentage of respondents who had correct knowledge on 3 items (out of the 13 items) returned to less than half, at 3 months follow-up. Four items were correctly responded by almost half, but the remaining were correctly known by more than $60 \%$ students. 
Table 3

Percentage distribution of correct knowledge on items regarding $\mathrm{RH}(\mathrm{n}=130)$.

\begin{tabular}{|c|c|c|c|}
\hline \multirow[t]{2}{*}{ Knowledge on items regarding $\mathrm{RH}$} & PI & IP & 3-MF \\
\hline & $\mathrm{n}(\%)$ & $\mathrm{n}(\%)$ & $\mathrm{n}(\%)$ \\
\hline Age at which menarche starts & $\begin{array}{l}60 \\
(46.2)\end{array}$ & $\begin{array}{l}90 \\
(69.2)\end{array}$ & $\begin{array}{l}70 \\
(53.8)\end{array}$ \\
\hline $\begin{array}{l}\text { The correct time at which a woman gets pregnant within the } \\
\text { menstrual cycle }\end{array}$ & $\begin{array}{l}24 \\
(18.5)\end{array}$ & $\begin{array}{l}85 \\
(65.4)\end{array}$ & $\begin{array}{l}65 \\
(50.0)\end{array}$ \\
\hline $\begin{array}{l}\text { Whether a woman can get pregnant on the first time of sexual } \\
\text { intercourse }\end{array}$ & $\begin{array}{l}63 \\
(48.5)\end{array}$ & $\begin{array}{l}90 \\
(69.2)\end{array}$ & $\begin{array}{l}82 \\
(63.1)\end{array}$ \\
\hline $\begin{array}{l}\text { Whether a girl stops growing after she makes sexual intercourse for } \\
\text { the first time }\end{array}$ & $\begin{array}{l}104 \\
(80.0)\end{array}$ & $\begin{array}{l}126 \\
(96.9)\end{array}$ & $\begin{array}{l}121 \\
(93.1)\end{array}$ \\
\hline $\begin{array}{l}\text { Whether a woman is most likely to get pregnant if she has sexual } \\
\text { intercourse half way between her periods }\end{array}$ & $\begin{array}{l}34 \\
(26.2)\end{array}$ & $\begin{array}{l}89 \\
(68.5)\end{array}$ & $\begin{array}{l}69 \\
(53.1)\end{array}$ \\
\hline $\begin{array}{l}\text { Whether a girl can take emergency contraceptives after every sexual } \\
\text { intercourse }\end{array}$ & $\begin{array}{l}33 \\
(25.4)\end{array}$ & $\begin{array}{l}76 \\
(58.5)\end{array}$ & $\begin{array}{l}58 \\
(44.6)\end{array}$ \\
\hline What method of EC have they heard? & $\begin{array}{l}39 \\
(30.0)\end{array}$ & $\begin{array}{l}100 \\
(76.9)\end{array}$ & $\begin{array}{l}71 \\
(54.6)\end{array}$ \\
\hline Which method of contraceptives are suitable for adolescents? & $\begin{array}{l}33 \\
(25.4)\end{array}$ & $\begin{array}{l}80 \\
(61.5)\end{array}$ & $\begin{array}{l}53 \\
(40.8)\end{array}$ \\
\hline $\begin{array}{l}\text { The female should carry EC pill with her, so that she can use it after } \\
\text { sex }\end{array}$ & $\begin{array}{l}44 \\
(33.8)\end{array}$ & $\begin{array}{l}98 \\
(75.4)\end{array}$ & $\begin{array}{l}84 \\
(64.6)\end{array}$ \\
\hline EC can protect from STI & $\begin{array}{l}45 \\
(34.6)\end{array}$ & $\begin{array}{l}90 \\
(69.2)\end{array}$ & $\begin{array}{l}86 \\
(66.2)\end{array}$ \\
\hline Use of EC will harm pregnancy & $\begin{array}{l}34 \\
(26.2)\end{array}$ & $\begin{array}{l}112 \\
(86.2)\end{array}$ & $\begin{array}{l}96 \\
(73.8)\end{array}$ \\
\hline $\begin{array}{l}\text { EC should be taken with knowledge and consultation of a health } \\
\text { care provider }\end{array}$ & $\begin{array}{l}86 \\
(66.2)\end{array}$ & $\begin{array}{l}109 \\
(83.8)\end{array}$ & $\begin{array}{l}92 \\
(70.8)\end{array}$ \\
\hline When is EC taken? & $\begin{array}{l}7 \\
(5.4)\end{array}$ & $84(64.6)$ & $52(40.0)$ \\
\hline
\end{tabular}

\section{Effect of Intervention through time on knowledge regarding $\mathrm{RH}$}

The mean (SD) scores of knowledge on RH at time 1 (pre-intervention), Time 2 (immediate post) and Time 3(3-months follow-up) were 6.57 (2.08), 9.26 (2.14), and 8.46 (2.69) out of 13 respectively (Table 4). 
Mauchly's test indicated that there was an evidence of non-sphericity (Mauchly's W $=0.931, p=0.010$ ). Hence, significant effect for time (Wilks' Lambda $=0.508, \mathrm{~F}(2,128)=61.95, p<0.001$ ), was observed using multivariate ANOVA.

Table 4

Level of knowledge regarding $\mathrm{RH}$ and the effect of educational intervention through time $(\mathrm{n}=130)$.

\begin{tabular}{|llll|}
\hline Time Period & N & Mean (SD) & Effect with time \\
\hline Time 1 (Pre-intervention) & 130 & $6.57(2.08)$ & Wilk's $\lambda=0.508$, \\
\cline { 1 - 3 } Time 2 (Immediate Post) & 130 & $9.26(2.14)$ & $\mathrm{F}(2,128)=61.95$, \\
\cline { 1 - 3 } Time 3 (3-month follow-up) & 130 & $8.46(2.69)$ & $\mathrm{p}<0.001$ \\
\cline { 1 - 4 }
\end{tabular}

Pairwise comparisons of the knowledge scores at the three time periods were also done using Bonferroni post-hoc test (Table 5 ). The test showed that knowledge scores were significantly higher at immediate post intervention than pre-intervention $(p<0.001), 3$-months follow-up than pre-intervention $(p<0.001)$, and immediate post intervention than 3 months later $(p=0.005)$. The trend of knowledge scores regarding $\mathrm{RH}$ was observed to be quadratic across the three time periods $(p<0.001)$.

Table 5

Pair-wise comparison of knowledge scores regarding $\mathrm{RH}$ at pre-intervention, immediate post, and 3-months follow-up $(n=130)$.

\begin{tabular}{|llll|}
\hline Post-hoc Comparison & MD (95\% Cl) & p-value & $\begin{array}{l}\text { p-value } \\
\text { trend }\end{array}$ \\
\hline Immediate Post and pre-intervention & $2.69(2.11,3.28)$ & $<0.001$ & $<0.001$ \\
\hline 3-months follow-up and pre-intervention & $1.89(1.18,2.61)$ & $<0.001$ & Quadratic \\
\hline Immediate Post and 3-months follow-up & $-0.80(-1.40,-0.20)$ & 0.005 & \\
\hline
\end{tabular}

\section{Positive attitude on $\mathrm{RH}$}

From 23 items proposed to assess the attitude towards $\mathrm{RH}$, less than half of the study participants were found to have positive attitude in 11 items during pre-intervention. At pre-intervention, the percentage of female students who had positive attitude towards avoiding sex before they become engaged and sex only for one time is not good were $78.5 \%$ and $70.0 \%$ respectively. On the other hand, only one fourth of the female students had a positive attitude on how to use a condom properly (being in favour of abstinence).

At immediate post intervention, less than half of the study participants were found to have a positive attitude in 7 items. Friends never think of having an abortion (32.3\%), and friends believe that you should 
be in love before you have sex with someone $(30.8 \%)$ were the least improved items at immediate after intervention. Avoiding sex before they become engaged (78.5\%), and sex for only one time should be avoided (76.2\%) were the two items in which the students had relatively higher positive attitude. At 3months follow-up, less than half of the study participants were found to have positive attitude in 11 items out of the 23 items. 
Table 6

Percentage distribution of positive attitude on RH $(n=130)$.

\begin{tabular}{|c|c|c|c|}
\hline \multirow[t]{2}{*}{ Attitude on ... } & \multirow{2}{*}{$\begin{array}{l}\mathrm{PI} \\
\mathrm{n}(\%)\end{array}$} & \multirow{2}{*}{$\begin{array}{l}\text { IP } \\
\mathrm{n}(\%)\end{array}$} & \multirow{2}{*}{$\begin{array}{l}\text { 3-MF } \\
\mathrm{n}(\%)\end{array}$} \\
\hline & & & \\
\hline Sex education should be given to teenagers & $\begin{array}{l}83 \\
(63.8)\end{array}$ & $95(73.1)$ & $\begin{array}{l}82 \\
(63.1)\end{array}$ \\
\hline Alright for unmarried boys and girls to date & $\begin{array}{l}41 \\
(31.5)\end{array}$ & $\begin{array}{l}52 \\
(40.0)\end{array}$ & $\begin{array}{l}45 \\
(34.6)\end{array}$ \\
\hline $\begin{array}{l}\text { Alright for unmarried boys and girls to kiss, hug and touch each } \\
\text { other }\end{array}$ & $\begin{array}{l}86 \\
(66.2)\end{array}$ & $\begin{array}{l}89 \\
(68.5)\end{array}$ & $\begin{array}{l}80 \\
(61.5)\end{array}$ \\
\hline $\begin{array}{l}\text { It is wrong for unmarried boys and girls to have sexual intercourse } \\
\text { even if they love each other }\end{array}$ & $\begin{array}{l}87 \\
(66.9)\end{array}$ & $\begin{array}{l}98 \\
(75.4)\end{array}$ & $\begin{array}{l}94 \\
(72.3)\end{array}$ \\
\hline A boy has to force a girl to have sex if he loves her & $\begin{array}{l}76 \\
(58.5)\end{array}$ & $\begin{array}{l}94 \\
(72.3)\end{array}$ & $\begin{array}{l}83 \\
(63.8)\end{array}$ \\
\hline A boy will not respect a girl who has sex with him & $\begin{array}{l}43 \\
(33.1)\end{array}$ & $\begin{array}{l}51 \\
(39.2)\end{array}$ & $\begin{array}{l}48 \\
(36.9)\end{array}$ \\
\hline Most girls who have sex before marriage regret it afterwards & $\begin{array}{l}88 \\
(67.7)\end{array}$ & $\begin{array}{l}91 \\
(70.0)\end{array}$ & $\begin{array}{l}55 \\
(42.3)\end{array}$ \\
\hline A boy and a girl should avoid sex before they become engaged & $\begin{array}{l}102 \\
(78.5)\end{array}$ & $\begin{array}{l}115 \\
(88.5)\end{array}$ & $\begin{array}{l}82 \\
(63.1)\end{array}$ \\
\hline Girls should remain virgin until they marry & $\begin{array}{l}62 \\
(47.7)\end{array}$ & $\begin{array}{l}70 \\
(53.5)\end{array}$ & $\begin{array}{l}57 \\
(43.8)\end{array}$ \\
\hline Sex only for one time is not good & $\begin{array}{l}99 \\
(76.2)\end{array}$ & $\begin{array}{l}111 \\
(85.4)\end{array}$ & $\begin{array}{l}100 \\
(76.9)\end{array}$ \\
\hline $\begin{array}{l}\text { I am confident that I can insist on use of condom every time I have } \\
\text { sex }\end{array}$ & $\begin{array}{l}66 \\
(50.8)\end{array}$ & $\begin{array}{l}75 \\
(57.7)\end{array}$ & $72(55.4)$ \\
\hline I would not support for a girl to have an abortion & $\begin{array}{l}49 \\
(37.7)\end{array}$ & $\begin{array}{l}72 \\
(55.4)\end{array}$ & $\begin{array}{l}55 \\
(42.3)\end{array}$ \\
\hline A girl should be in love before having sex with a boy & $\begin{array}{l}47 \\
(36.2)\end{array}$ & $\begin{array}{l}46 \\
(35.4)\end{array}$ & $\begin{array}{l}46 \\
(35.4)\end{array}$ \\
\hline Know how to use a condom properly (Being in favour of abstinence) & $\begin{array}{l}23 \\
(17.7)\end{array}$ & $\begin{array}{l}30 \\
(23.1)\end{array}$ & $\begin{array}{l}56 \\
(43.1)\end{array}$ \\
\hline Friends never think of having an abortion & $\begin{array}{l}42 \\
(32.3)\end{array}$ & $\begin{array}{l}55 \\
(42.3)\end{array}$ & $\begin{array}{l}47 \\
(40.0)\end{array}$ \\
\hline $\begin{array}{l}\text { Friends believe that you should be in love before you have sex with } \\
\text { someone (Being in favor of abstinence) }\end{array}$ & $\begin{array}{l}40 \\
(30.8)\end{array}$ & $\begin{array}{l}54 \\
(41.5)\end{array}$ & $\begin{array}{l}47 \\
(36.2)\end{array}$ \\
\hline
\end{tabular}

$P I=$ Pre-intervention, IP = Immediate Post, $3-M F=$ Three months follow-up . 


\begin{tabular}{|llll|}
\hline Attitude on ... & $\mathbf{P I}$ & IP & 3-MF \\
\cline { 2 - 4 } & $\mathbf{n}(\%)$ & $\mathbf{n}(\%)$ & $\mathbf{n}(\%)$ \\
\hline No to have sex without condom (Being in favour of abstinence) & 57 & 71 & 60 \\
& $(43.8)$ & $(54.6)$ & $(46.2)$ \\
\hline Sex for only one time should be avoided & 91 & 112 & 110 \\
& $(70.0)$ & $(86.2)$ & $(84.6)$ \\
\hline EC should be available at health facilities & 73 & 115 & 101 \\
& $(56.2)$ & $(88.5)$ & $(77.7)$ \\
\hline It is not alright for girls to have sex even if they use methods to stop & 37 & 44 & 70 \\
pregnancy & $(28.5)$ & $(33.1)$ & $(53.8)$ \\
\hline It is mainly the woman's responsibility to use contraceptive regularly & 37 & 60 & 49 \\
& $(28.5)$ & $(46.2)$ & $(37.7)$ \\
\hline They are not concerned about confidentiality & 79 & 101 & 90 \\
\hline The girl shouldn't carry the EC in her bag & $(60.8)$ & $(77.7)$ & $(69.2)$ \\
\hline PI = Pre-intervention, IP = Immediate Post, 3-MF = Three months follow-up. & & \\
\hline
\end{tabular}

\section{Effect of Intervention through time on Attitude towards RH}

The mean (SD) scores of attitude towards RH at time 1 (pre-intervention), Time 2 (immediate post) and Time 3 (three month follow-up) were 48.98 (4.68), 51.03 (4.04), and 49.65 (4.01)out of 69 respectively (Table 7).

Mauchly's test indicated that there was an evidence of non-sphericity (Mauchly's W $=0.951, p=0.040$ ). Multivariate ANOVA showed significant effect for time (Wilks' Lambda $=0.827, \mathrm{~F}(2,128)=13.42, p<$ 0.001).

Table 7

Level of attitude regarding $\mathrm{RH}$ and the effect of educational intervention through time $(n=130)$.

\begin{tabular}{|llll|}
\hline Time Period & N & Mean (SD) & Effect with time \\
\hline Time 1 (Pre-intervention) & 130 & $48.98(4.68)$ & Wilk's $\lambda=0.827$, \\
\cline { 1 - 3 } Time 2 (Immediate Post) & 130 & $51.03(4.04)$ & $\mathrm{F}(2,128)=13.42$, \\
\cline { 1 - 3 } Time 3 (3-month follow-up) & 130 & $49.65(4.01)$ & $\mathrm{p}<0.001$ \\
\hline
\end{tabular}


Table 8 shows the pairwise comparison of attitude scores regarding $\mathrm{RH}$. Bonferroni post-hoc test showed that attitude scores was significantly higher at immediate post intervention than pre-intervention $(p<$ $0.001)$ and immediate post intervention than 3 months follow-up $(p=0.001)$. However, no significant difference in attitude scores was found between 3 months follow-up and pre-intervention $(p=0.395)$. The trend of attitude towards $\mathrm{RH}$ and pregnancy scores was observed to be quadratic across the three time periods $(p<0.001)$.

Table 8

Pair-wise comparison of attitude scores regarding $\mathrm{RH}$ at pre-intervention, immediate post, and 3-months follow-up $(n=130)$

\begin{tabular}{|llll|}
\hline Post-hoc Comparison & $\mathrm{MD}(95 \% \mathrm{Cl})$ & p-value & p-value trend \\
\hline Immediate post and pre-intervention & $2.05(1.01,3.10)$ & $<0.001$ & $<0.001$ \\
\hline 3 months later and pre-intervention & $0.68(-0.41,1.76)$ & 0.395 & Quadratic \\
\hline Immediate post and 3 months later & $1.38(0.48,2.27$ & 0.001 & \\
\hline
\end{tabular}

\section{Effectiveness of Educational Intervention on Knowledge regarding $\mathrm{RH}$ by demographic variables}

Analysis using mixed between-within subjects analysis of variance was conducted to assess the impact of the educational intervention on the scores of knowledge about $\mathrm{RH}$ across three time periods by age, religion, discussion of sexual issues with father, discussion of sexual issues with mother, presence of elder sister, educational level of father and educational level of mother (Table 9). The result revealed no significant interaction between age group and time (Wilk's Lambda $=0.991, p=0.560$ ), discussion of sexual issues with father (Wilk's Lambda $=0.981, p=0.662$ ), mother (Wilk's Lambda $=0.975, p=0.529$ ), presence of elder sister (Wilk's Lambda $=0.978, p=0.242$ ), educational level of father (Wilk's Lambda $=$ $0.986, p=0.782$ ) and mother (Wilk's Lambda $=0.964, p=0.274$ ). However, there was significant interaction between religion and time (Wilk's Lambda $=0.950, p=0.040$ ). 
Table 9

Effectiveness of educational intervention on knowledge of RH by background characteristics $(n=130)$.

\begin{tabular}{|c|c|c|c|c|c|c|}
\hline \multirow[t]{2}{*}{ Characteristics } & PI & IP & 3-MF & \multirow[t]{2}{*}{$\begin{array}{l}\text { Box } \\
\text { M }\end{array}$} & \multirow[t]{2}{*}{$\begin{array}{l}\text { Wilk's } \\
\text { Lambda }\end{array}$} & \multirow[t]{2}{*}{$\begin{array}{l}p- \\
\text { value }\end{array}$} \\
\hline & $M(S D)$ & $M(S D)$ & $M(S D)$ & & & \\
\hline \multicolumn{7}{|l|}{ Age } \\
\hline 13 to 15 & $\begin{array}{l}6.69 \\
(2.09)\end{array}$ & $9.20(2.08)$ & $\begin{array}{l}8.37 \\
(2.52)\end{array}$ & 0.426 & 0.991 & 0.560 \\
\hline 16 to 18 & $\begin{array}{l}6.37 \\
(2.08)\end{array}$ & $9.37(2.25)$ & $\begin{array}{l}8.61 \\
(2.98)\end{array}$ & & & \\
\hline
\end{tabular}

Religion

$\begin{array}{lllllll}\text { Christian } & \begin{array}{l}6.46 \\ (2.05)\end{array} & 9.17(2.17) & \begin{array}{l}8.55 \\ (2.66)\end{array} & 0.364 & 0.950 & 0.040 * \\ \text { Muslim } & 7.73 & 10.27 & 7.55 & & & \\ & (2.15) & (1.49) & (3.01) & & & \end{array}$

Sex Issues Discussion with Father

$\begin{array}{lllllll}\text { Always/Frequently } & \begin{array}{l}6.05 \\ (1.80)\end{array} & 9.00(2.29) & \begin{array}{l}7.97 \\ (2.66)\end{array} & 0.628 & 0.981 & 0.662 \\ \text { Sometimes } & \begin{array}{l}6.89 \\ (2.04)\end{array} & 9.00(1.90) & \begin{array}{l}8.47 \\ (2.22)\end{array} & & \\ & & & & \\ \text { Rarely/Never } & 6.71 & 9.61(2.16) & \begin{array}{l}8.79 \\ (2.97)\end{array} & & \\ & (2.25) & & & & \end{array}$

Sex Issues Discussion with Mother

$\begin{array}{lllllll}\text { Always/Frequently } & \begin{array}{l}6.74 \\ (2.04)\end{array} & 9.04(2.25) & \begin{array}{l}8.06 \\ (2.60)\end{array} & 0.575 & 0.975 & 0.529 \\ \text { Sometimes } & \begin{array}{l}6.69 \\ (2.09)\end{array} & 9.65(1.81) & \begin{array}{l}8.85 \\ (2.63)\end{array} & & \\ & & & & \\ \text { Rarely/Never } & 5.91 & 9.87(2.49) & \begin{array}{l}8.48 \\ (2.99)\end{array} & & \end{array}$

Presence of elder sister

$\begin{array}{lllllll}\text { Yes } & 6.62 & 9.34(2.18) & \begin{array}{l}8.24 \\ (2.56)\end{array} & 0.497 & 0.978 & 0.242 \\ \text { No } & (2.18) & & & & \\ & 6.48 & 9.11(2.07) & \begin{array}{l}8.89 \\ (2.91)\end{array} & & & \\ & (1.90) & & & & \end{array}$

Father's Educational Level 


\begin{tabular}{|c|c|c|c|c|c|c|}
\hline \multirow[t]{2}{*}{ Characteristics } & PI & IP & 3-MF & \multirow{2}{*}{$\begin{array}{l}\text { Box } \\
M\end{array}$} & \multirow{2}{*}{$\begin{array}{l}\text { Wilk's } \\
\text { Lambda }\end{array}$} & \multirow{2}{*}{$\begin{array}{l}p- \\
\text { value }\end{array}$} \\
\hline & $M(S D)$ & $M(S D)$ & $M(S D)$ & & & \\
\hline Junior or below & $\begin{array}{l}6.58 \\
(2.26)\end{array}$ & $9.21(2.13)$ & $\begin{array}{l}8.12 \\
(2.09)\end{array}$ & 0.064 & 0.986 & 0.782 \\
\hline Secondary & $\begin{array}{l}6.32 \\
(2.21)\end{array}$ & $9.21(2.43)$ & $\begin{array}{l}8.13 \\
(2.69)\end{array}$ & & & \\
\hline Post-secondary & $\begin{array}{l}6.73 \\
(1.91)\end{array}$ & $9.26(2.14)$ & $\begin{array}{l}8.86 \\
(2.96)\end{array}$ & & & \\
\hline \multicolumn{7}{|c|}{ Mother's Educational Level } \\
\hline Junior or below & $\begin{array}{l}6.54 \\
(2.00)\end{array}$ & $9.04(2.43)$ & $\begin{array}{l}8.27 \\
(2.08)\end{array}$ & 0.090 & 0.964 & 0.274 \\
\hline Secondary & $\begin{array}{l}6.30 \\
(2.30)\end{array}$ & $9.78(1.67)$ & $\begin{array}{l}8.83 \\
(2 . .99)\end{array}$ & & & \\
\hline Post-secondary & $\begin{array}{l}6.89 \\
(1.96)\end{array}$ & $9.03(2.10)$ & $\begin{array}{l}8.34 \\
(3.11)\end{array}$ & & & \\
\hline
\end{tabular}

\section{Effectiveness of Educational Intervention on attitude on $\mathrm{RH}$ by demographic variables}

Analysis using mixed between-within subjects analysis of variance was conducted to assess the impact of the educational intervention on the scores of attitude on $\mathrm{RH}$ across three time periods by age, religion, discussion of sexual issues with father, discussion of sexual issues with mother, presence of elder sister, educational level of father and educational level of mother (Table 10). The result revealed no significant interaction between age group and time (Wilk's Lambda $=0.996, p=0.772$ ), religion and time (Wilk's Lambda $=0.982, p=0.308$ ), discussion of sexual issues with father (Wilk's Lambda $=0.966, p=0.357$ ), discussion of sexual issues with mother (Wilk's Lambda $=0.973, p=0.489$ ), presence of elder sister (Wilk's Lambda $=0.099, p=0.133$ ), and educational level of father (Wilk's Lambda $=0.940, p=0.099$ ). However, border significance of interaction was observed between educational level of mother and time (Wilk's Lambda $=0.927, p=0.049$ ). 
Table 10

Effectiveness of educational intervention on attitude of RH by background characteristics $(n=130)$.

\begin{tabular}{|c|c|c|c|c|c|c|}
\hline \multirow[t]{2}{*}{ Characteristics } & PI & IP & 3-MF & \multirow[t]{2}{*}{$\begin{array}{l}\text { Box } \\
M\end{array}$} & \multirow[t]{2}{*}{$\begin{array}{l}\text { Wilk's } \\
\text { Lambda }\end{array}$} & \multirow[t]{2}{*}{$\begin{array}{l}p- \\
\text { value }\end{array}$} \\
\hline & $M(S D)$ & $M(S D)$ & $M(S D)$ & & & \\
\hline \multicolumn{7}{|l|}{ Age } \\
\hline 13 to 15 & $\begin{array}{l}49.36 \\
(4.71)\end{array}$ & $\begin{array}{l}51.44 \\
(3.90)\end{array}$ & $\begin{array}{l}50.25 \\
(3.66)\end{array}$ & 0.515 & 0.996 & 0.772 \\
\hline 16 to 18 & $\begin{array}{l}48.35 \\
(4.61)\end{array}$ & $\begin{array}{l}50.35 \\
(4.21)\end{array}$ & $\begin{array}{l}48.67 \\
(4.40)\end{array}$ & & & \\
\hline
\end{tabular}

Religion

$\begin{array}{lllllll}\text { Christian } & 48.76 & 51.01 & 49.62 & 0.500 & 0.982 & 0.308 \\ & (4.63) & (4.12) & (4.13) & & & \\ \text { Muslim } & 51.27 & 51.27 & 50.00 & & & \\ & (4.84) & (3.23) & (2.37) & & & \end{array}$

Sex Issues Discussion with Father

$\begin{array}{lllllll}\text { Always/Frequently } & \begin{array}{l}47.21 \\ (3.89)\end{array} & \begin{array}{l}49.84 \\ (4.08)\end{array} & \begin{array}{l}48.84 \\ (3.85)\end{array} & 0.734 & 0.966 & 0.357 \\ \text { Sometimes } & 48.86 & 51.47 & 50.17 & & & \\ & (5.31) & (4.11) & (4.15) & & & \\ \text { Rarely/Never } & 50.25 & 51.55 & \begin{array}{l}49.88 \\ (4.01)\end{array} & & \\ & (4.40) & (3.87) & (40) & & \end{array}$

Sex Issues Discussion with Mother

$\begin{array}{lllllll}\text { Always/Frequently } & \begin{array}{l}48.68 \\ (4.13)\end{array} & \begin{array}{l}49.96 \\ (4.10)\end{array} & \begin{array}{l}49.25 \\ (4.09)\end{array} & 0.204 & 0.973 & 0.489 \\ & & & & \\ \text { Sometimes } & 48.93 & 51.61 & 49.87 & & & \\ & (5.26) & (3.91) & (3.93) & & & \\ \text { Rarely/Never } & 49.78 & 52.03 & 50.09 & & \\ & (4.55) & (4.04) & (4.10) & & \end{array}$

Presence of elder sister

$\begin{array}{lllllll}\text { Yes } & 48.81 & 51.29 & 49.42 & 0.099 & 0.969 & 0.133 \\ & (5.02) & (4.16) & (4.19) & & & \\ \text { No } & 49.30 & 50.52 & 50.11 & & & \\ & (3.97) & (3.79) & (3.64) & & & \end{array}$

Father's Educational Level 


\begin{tabular}{|c|c|c|c|c|c|c|}
\hline \multirow[t]{2}{*}{ Characteristics } & PI & IP & 3-MF & \multirow{2}{*}{$\begin{array}{l}\text { Box } \\
M\end{array}$} & \multirow{2}{*}{$\begin{array}{l}\text { Wilk's } \\
\text { Lambda }\end{array}$} & \multirow{2}{*}{$\begin{array}{l}p- \\
\text { value }\end{array}$} \\
\hline & $M(S D)$ & $M(S D)$ & $M(S D)$ & & & \\
\hline Junior or below & $\begin{array}{l}49.12 \\
(4.77)\end{array}$ & $\begin{array}{l}50.06 \\
(3.94)\end{array}$ & $\begin{array}{l}50.15 \\
(3.75)\end{array}$ & 0.479 & 0.940 & 0.099 \\
\hline Secondary & $\begin{array}{l}47.97 \\
(4.45)\end{array}$ & $\begin{array}{l}51.26 \\
(4.68)\end{array}$ & $\begin{array}{l}49.08 \\
(3.74)\end{array}$ & & & \\
\hline Post-secondary & $\begin{array}{l}49.54 \\
(4.74)\end{array}$ & $\begin{array}{l}51.42 \\
(3.61)\end{array}$ & $\begin{array}{l}49.75 \\
(4.32)\end{array}$ & & & \\
\hline \multicolumn{7}{|c|}{ Mother's Educational Level } \\
\hline Junior or below & $\begin{array}{l}48.54 \\
(4.48)\end{array}$ & $\begin{array}{l}50.48 \\
(4.43)\end{array}$ & $\begin{array}{l}49.40 \\
(3.88)\end{array}$ & 0.314 & 0.927 & $0.049 *$ \\
\hline Secondary & $\begin{array}{l}48.58 \\
(3.95)\end{array}$ & $\begin{array}{l}51.85 \\
(4.15)\end{array}$ & $\begin{array}{l}50.80 \\
(3.86)\end{array}$ & & & \\
\hline Post-secondary & $\begin{array}{l}50.00 \\
(5.54)\end{array}$ & $\begin{array}{l}50.92 \\
(3.25)\end{array}$ & $\begin{array}{l}48.79 \\
(4.15)\end{array}$ & & & \\
\hline
\end{tabular}

\section{Discussion}

Basically, the purpose of health education is to eliminate undesirable behaviours and replace them with appropriate and productive behaviour leading to healthy life. This study sought to answer the question of whether training given to female adolescents in high schools had an effect in bringing a positive change in their knowledge and attitude towards $\mathrm{RH}$ and especially on emergency contraceptives.

Adolescent $\mathrm{RH}$ is a major public health challenge. This study similar to the preceding studies revealed that heterosexual romantic relationship among adolescents is rampant [6]. What makes the problem more challenging is the lack of correct information which can help them make informed decisions. As a result unplanned pregnancies that lead to forced unplanned marriages, school dropout and academic failure is the consequence. To achieve the Sustainable Development Goals, adolescents who are the future potential workforce of the nation should be empowered through correct and relevant $\mathrm{RH}$ information. Creating a favourable and safe environment for female students to free them from vicious cycle of poverty and ignorance appears to be a very important step.

\section{Knowledge on RH}

The overall mean knowledge score of study participants in this study significantly increased from $6.28 / 13$ at preintervention to $9.26 / 13$ immediate after intervention which later decreased to $8.46 / 13$ three months later. As to the decline in the level of retention in the third assessment, the knowledge they 
acquired appears to be temporary meaning the knowledge is dissipating after a short period. This can be related to several aspects of the training. First, the duration of the training was for an hour a day, and for fourteen days only. More training time may be needed to improve the retention of the knowledge. Instead of giving the training outside their regular education, this research believes a better result could be achieved if it is given as part of their regular subject training at 9th and 10th grade for two consecutive years. This time is preferred to later time on the ground that the students require knowledge on EC before the advent of any emergency incidence that can lead to pregnancy. The reason for extending the training in a two years program is to enable the students to acquire knowledge that can be retained in a permanent one, and not something that disappears shortly as seen in this study. Moreover if it is to be given as a regular program, students could have more time for discussion and question. With the same contents, the training to be provided for the future could be prepared tailored to their level in a more simplified way. The authors also recommend that the training be supported by reading materials that is simple to understand and, preferably in Tigrigna language or in the language that the students can understand better for those who are not Tigrigna speakers. It is the general belief of this study that the above condition may improve the retention level of the students.

Comparing this study with various studies outcomes, the results appear to be similar. The following studies could be mentioned as some. Evaluation of a school based RH education program in rural south western Nigeria indicated that the intervention school showed a significantly higher knowledge scores than the control group at follow up [24]. A significant increase for the total sample in knowledge regarding puberty and menstruation was observed post intervention [25]. In a study by Eman Elsayed, the overall adequate knowledge significantly improved from 21.3 to $82.7 \%$ after intervention [26]. A similar result was also observed in a study where the girls' mean knowledge score significantly increased from 5.9 to 6.8 in post-test [27]. Another similar study also showed that the knowledge of girls regarding health aspects improved significantly after intervention [28]. Moreover, the mean score of knowledge for an intervention group in a study by Ibrahim et al., increased from 60.49 to 141.3 [29]. This similarities show the effectiveness of RH education in improving knowledge of adolescent girls. Majority of the studies were conducted in secondary schools where the literacy is better and the education received is better. The study sites which are the secondary schools in this study are located in an urban area. This could also have contributed to the positive effect of education provided. The result of this and the relevant literatures also made clear that schools are the best avenue to educate adolescents about $\mathrm{RH}$ using an acceptable strategy.

An indicator of knowledge on $\mathrm{RH}$, the time at which a woman gets pregnant, was initially found to be very low $(18.5 \%)$, though it increased to $65.4 \%$ in the immediate after intervention. This improvement is not only encouraging but also desirable because acquisition of knowledge is usually the first step in change of behaviour. The pre-test finding of this study is similar to a previous study done in Eritrea [6] that showed only $17 \%$ knew the days of ovulation, $65 \%$ have never been exposed to any family planning information, $66 \%$ lack knowledge on STIs. This shows that the area of RH in Eritrea has been neglected or no intervention has ever been proposed to avert the lack of knowledge on $\mathrm{RH}$. The main problem also

Page 22/30 
appears to be that adolescents' main source of RH information are their life skill teachers who lack the exact and correct knowledge of $\mathrm{RH}$ like themselves.

\section{Knowledge on EC}

Of all the study participants, $30.0 \%$ have heard of the methods of EC at the initial assessment. After training, $76.9 \%$ of the students were able to have the correct knowledge on EC. In a similar study from Nigeria the awareness of the existence of EC among students was $71.3 \%$ at first, that increased to $100 \%$ after the intervention [15]. A study conducted in 2013 to assess knowledge of EC among high school students in Mekele (Ethiopia) showed that $75.7 \%$ of the respondents had awareness of EC [30] which is higher when compared to the baseline assessment of the current study. The baseline assessment of this study was also found to vary among different studies. Characteristics of the study participants could have brought the difference as some studies are conducted in high schoolers and others in university students. The interventional nature of this study is also believed to have some effect on the difference. Knowledge on correct time when EC should be taken increased from $5.4-64.6 \%$ in this study. This when compared to a Nigerian study is higher $(2-20.7 \%)$ and it could be attributed to the carefully designed and implemented educational program of this study [24]

In the present study, 8 (50\%) of the 16 students who experienced sexual intercourse was by force (not shown in the results section). This is worrisome and risky, because, they were exposed to unsafe sex (rape) without having adequate knowledge on how to prevent pregnancy in times of emergency. Few of the remaining students used contraceptives prior to sexual act. None of them had knowledge of EC. Those who became pregnant could have prevented it if they have had adequate knowledge about EC. Such incidences are public health challenge, and call for a concerted national efforts to equip adolescents with appropriate $\mathrm{RH}$ knowledge that can help them to prevent risk.

\section{Attitude on RH}

The mean (SD) scores of attitude towards RH significantly increased at three time periods 1 (preintervention), Time 2 (immediate post) and Time 3 (three-month follow-up) were 48.98 (4.68), 51.03 (4.04), and 49.65 (4.01) out of 69 respectively. Significant improvement in attitude was also evidenced in a study by (difference $=16.8 ; 95 \% \mathrm{Cl}: 15.3,18.3)$, [16]. The change in attitude is encouraging since attitude is a predictor of intentions to undertake any behaviour. It indicates the intensity of individuals' motivation and attempts to perform a task. This result indicates that such kind of training is highly needed in all schools that should be given at an earlier age. In a comparative study, the attitude score did not show a statistically significant difference between pre-test and post-test [27] and the authors concluded that attitude may not be easy to change.

A very similar proportion of respondents in this study and a study by ghebreyohannes ( $95 \%$ and $90 \%$ respectively) were against having sexual intercourse before marriage. The results of this study appear to be reassuring given that the social norm and culture that rejects premarital sex and practice is losing ground nowadays. A positive effect of the intervention is seen in the discussion of sex education to teenagers (from $63.8 \%$ pre intervention to $73.1 \%$ post intervention). This is promising given the traditional 
social context and conservative nature of the Eritrean society does not allow open discussions regarding sexuality. One condition that leads girls to take risk is, thinking that "one time sex may not be a problem." However, the respondents seem well aware of the problem that comes out of this, $70.0 \%$ at first, $86.2 \%$ at second, and $84.6 \%$ at last were against experimenting for one time as a safe one.

In trying to find out association between the response to attitude questions the adolescent students gave, with their personal and family characteristics, there was no significant interaction between age group, religion, discussion of sexual issues with father, and mother, presence of elder sister, educational level of father, but a borderline of significance was observed with mother's educational level. This result is a sign that there was less positive attitude across most categories of background characteristics. This fact makes preparing a one and only teaching module easier as the prepared module can be equally effective for adolescent girls of various background characteristics. The borderline significance enlightens the complete frankness needed with adolescents especially in the prepubescent period which can be achieved when mothers are of a higher literacy and awareness. That way the issues related to $\mathrm{RH}$ which are still treated with certain amount of secrecy and reticence can be breached. This can consequently enable adolescents to accept the natural changes in a healthy manner.

\section{Attitude on EC}

The attitude aspect of emergency contraceptive is important as it identifies the potential users of it in the future [31]. The attitude on EC among students in this study showed a significant improvement after receiving training. Studies have reported about students' attitudes toward EC. A study in Mekele reported that $64 \%$ of students had p.'.gositive attitude towards EC [32]. In Araba Minch [33], $60 \%$ of university students used EC, and more than $95 \%$ have positive attitude towards using EC. In Nigeria, despite their positive attitude towards EC, there were insignificant numbers who opposed the use of EC on the ground that the opportunity would be abused in a regular manner [15].

The training given to adolescent girls should emphasize on avoidance of sex at the level of secondary schools. This is so because initiating sexual intercourse at that level will be a hindrance to their learning. If they, however, prefer to initiate sex at that level, they should avoid unprotected sexual intercourse. If, for any reason, unprotected sexual intercourse is performed, the adolescents should have the knowledge that there is emergency contraceptive as a last solution to avoid pregnancy. Training or awareness can be delivered in different forms, formal training in schools, through mass media, and youth clubs. The focus should be on the benefits and methods on how to use emergency contraceptives. Parental control on adolescents should also continue.

The type of training being provided by life skill or science teachers should be replaced by regular and formal training. Female adolescents do live mixed with boys; therefore, the knowledge of girls alone is not enough, the same awareness should be shared by boys. There is a need for an intersectoral, holistic approach to adolescent health involving all sectors including the health, education, youth, sports, social welfare sectors as well as the media. The formulation of a national policy for adolescents should be considered as a long-term requirement. A national intersectoral committee should be established and 
charged with the responsibility of raising the quality of life of adolescents to prepare them for their future lives. As to the strategy to raise awareness and increase knowledge and positive attitude towards $\mathrm{RH}$ and EC, the Ministry of Health and MOE should agree upon the best mechanism to deliver training to students.

Adolescents outside the regular schools should also benefit from such training. This can be provided in a separate training at youth clubs in all localities; this can be supplemented by the same training that can be given on TV, Radio, and newspaper programs. Further research is needed to better understand the potential for alternative venues to provide adolescent $\mathrm{RH}$ education and services and ways in which programmes can be expanded, scaled up and evaluated. The studies to be done should include intervention of training, and a separate study on boys that include secondary schools even in remote areas of Eritrea. It should be noted that the findings of this survey cannot not be generalized to the entire adolescent population in Eritrea, as this was a school-based survey and it may not be generalized to illiterate adolescents. Therefore, there is a need for a large-scale nationwide survey that addresses both urban and rural areas adequately.

The following limitations need to be considered while interpreting the findings of the study. The possible effect of other sources like TV, books, magazines and radio broadcasting on the change in the knowledge and attitude of adolescent females on RH could not be controlled. In addition, the results are based on self-reports. Although every effort was made to assure the participants that their responses would be kept confidential, the possibility remains that some may have underreported their knowledge regarding sexuality or contraceptive methods to avoid embarrassment.

\section{Conclusion}

This study has shown that the well-designed intervention generally was effective in achieving improved knowledge and attitude of female adolescents towards $\mathrm{RH}$. The study also noted that the knowledge and attitude of participants showed a decreasing trend in retention after three months. This is an indication that there is a need for continuous availability of RH information for adolescents. Life skill teachers at the school were the primary source of information on $\mathrm{RH}(57.9 \%)$. Only $30 \%$ and $21.4 \%$ of the students always discuss sex-related issues with their mothers and fathers respectively. The item 'when is EC taken?' was the least (5.4\%) correctly known, followed by the correct time at which a woman gets pregnant within the menstrual cycle (18.5\%) before the intervention. Avoiding sex before they become engaged (78.5\%), and sex for only one time should be avoided (70\%) were the two items in which the students had relatively higher positive attitude. There was significant interaction between religion and time in change of knowledge scores and a border significance of interaction was observed between educational level of mother and time in change of attitude scores. Even though the result of change in knowledge and attitude of $\mathrm{RH}$ and $\mathrm{EC}$ found among the students in this study after the training is statistically significant, and is comparable to relevant studies, more training is needed to push their knowledge to higher level in order to allow the students to have a better $\mathrm{RH}$.

\section{Abbreviations}


ANOVA: Analysis of Variance; EC: Emergency Contraceptive; EPHS: Eritrea, Population and Health Survey; MOE: Ministry of Education, Eritrea; MOH; Ministry of Health, Eritrea; NSO: National Statistical Office; NUEW: National Union of Eritrean Women; RH: RH; SPSS: Statistical Package for Social Sciences; STD: Sexually Transmitted Diseases; WHO: World Health Organization

\section{Declarations}

\section{Ethical approval and consent to participate}

Clearance for the study was initially provided by the research and ethical committee of Asmara College of Health Sciences and Ministry of Health. The Ministry of Education head quarter and Zoba Maekel provided permission to conduct the study in the schools. The study participants were asked for their written consent after assuring confidentiality of the data. Under-age issue was discussed with the school directors, as a result of which letters were sent to the parents of the selected participants for their approval. The questionnaire was anonymous and data was secured.

\section{Consent for publication}

All authors read and approved the final manuscript

\section{Availability of data}

The complete dataset used and/or analyzed during the current study are available from the corresponding author and can be accessed upon reasonable request.

\section{Authors' contribution}

AW: Designed the study, coordinated recruitment of participants, education of participants, preparing of teaching materials and in writing of all drafts and final manuscript. GG: Designed the study, coordinated recruitment of participants, education of participants and participated in writing manuscript. LG: Coordinated recruitment of participants, education of participants, writing of all drafts and the final manuscript. EHT: Assured quality of data collection, led data analysis, writing manuscript, and in writing of all drafts and the final manuscript. All authors read and approved the final manuscript.

\section{Competing interest}

The authors declare that there is no conflict interest regarding the publication of this paper. 


\section{Funding}

This research was supported by the National Board of higher Education. The award grant numberis $25 / 08 / 18$. The funders had no role in study design, data collection and analysis, decision to publish, or preparation of the manuscript.

\section{Acknowledgements}

The authors would like to thank the participants who took part in this study, National Board of Higher Education (NBHE) for funding the research and for all who contributed one way or another to the successful completion of the project.

\section{References}

1. Krugu, J.K., et al., Who's that girl? A qualitative analysis of adolescent girls' views on factors associated with teenage pregnancies in Bolgatanga, Ghana. RH, 2016. 13(1): p. 1-12.

2. NSO, Population and Health Survey. Asmara, Eritrea: National Statistical Office. 2010.

3. Bronfenbrenner, U. and P.A. Morris, The ecology of developmental processes. 1998.

4. WHO, The Second Decade. Improving Adolescent Health and Development. 1998: Geneva.

5. NUEW, Formative Research on Drivers of Child Marriage in Eritrea. 2017, NUEW: Asmara, Eritrea.

6. Ghebreyohans, G., et al., Burden of RH Illiteracy in Eritrea. International Journal of Sciences: Basic and Applied Research (IJSBAR)... Journal of Adolescent Health, 2015. 55(32): p. 107-113.

7. NSO, Population and Health Survey. 2010, National Statistical Office: Asmara, Eritrea.

8. Trussell, J., Raymond, E. G., \& Cleland, K., Emergency contraception: a last chance to prevent unintended pregnancy. 2007.

9. Rivera, R., Contraceptives in Adolescence. 2004, WHO.

10. Gottschalk, L.B. and N. Ortayli, Interventions to improve adolescents' contraceptive behaviors in lowand middle-income countries: a review of the evidence base. Contraception, 2014. 90(3): p. 211-225.

11. Abdulrazaq, A., et al., The effect of educational intervention on family planning knowledge, attitudes, and practices among married women in a military barrack in northern Nigeria. African journal of RH, 2014. 18(1): p. 93-101.

12. UNFPA, Eritrea National Post Abortion Care Curriculum For Service Provider., ed. UNFPA. 2006, Asmara, Eritrea: UNFPA.

13. Sebhatu, B., et al., Determinants of immediate complications of abortion: A study done in Mekane Hiwet Maternity Hospital. Journal of the Eritrean Medical Association, 2006. 1(1).

14. Ghebrehiwet, M., et al., Magnitude and Causes of Maternal Deaths at Health Facilities in Eritrea in 2007. Journal of the Eritrean Medical Association, 2009. 4(1): p. 22-25. 
15. Arinze-Onyia, S., et al., The effects of health education on knowledge and attitudes to emergency contraception by female students of a Tertiary Educational Institution in Enugu, South East Nigeria. Nigerian Journal of Physiological Sciences, 2010. 25(2): p. 165-171-165-171.

16. Darabi, F., et al., The effect of a theory of planned behavior-based educational intervention on sexual and $R H$ in Iranian adolescent girls: a randomized controlled trial. Journal of research in health sciences, 2017. 17(4): p. 400.

17. MOE, Basic Education Statistics. In M. o. Education (Ed.). Eritrea. 2018.

18. Cleland, J., Illustrative questionnaire for interview-surveys with young people. Asking Young People About Sexual and Reproductive Behaviors. Illustrative Core Instruments, Geneva: World Health Organization, 2001.

19. Adelson, E.M., Sexual health and psychological well-being of unmarried adolescent females living in an urban slum in India. 2014, Tulane University School of Science and Engineering.

20. Fekadu, Y., Knowledge attitude and utilization of emergency contraception among health science and medical students of Arba Minch University, 2015. 2017.

21. Hossain, S.M., et al., Emergency Contraceptive Pills: South East Asia Regional Training Manual. 2005.

22. Hossain, S.M., et al., ECP handbook: Introducing and mainstreaming the provision of emergency contraceptive pills in developing countries. 2009.

23. Cunningham, F., et al., Williams Obstetrics 23rd Edition McGraw Hill. New York, 2010. 2010.

24. Ajuwon, A.J. and W.R. Brieger, Evaluation of a school-based RH education program in rural South Western, Nigeria. African journal of RH, 2007. 11(2): p. 47-59.

25. Tork, H.M.M., Effects of RH education on knowledge and attitudes among female adolescents in Saudi Arabia. Journal of Nursing Research, 2015. 23(3): p. 236-242.

26. Elsabagh, E.E.M., Effect of Health Education Intervention on Knowledge and Practice about $R H$ among Adolescent Female Students. 2017.

27. Madeni, F., S. Horiuchi, and M. lida, Evaluation of a RH awareness program for adolescence in urban Tanzania-A quasi-experimental pre-test post-test research. RH, 2011. 8(1): p. 1-9.

28. Kotwal, N., N. Khan, and S. Kaul, A review of the effectiveness of the interventions on adolescent $R H$ in developing countries. International Journal of Scientific and Research Publications, 2014. 4(5): p. 1-4.

29. Yakubu, l., et al., Assessing the impact of an educational intervention program on sexual abstinence based on the health belief model amongst adolescent girls in Northern Ghana, a cluster randomised control trial. RH, 2019. 16(1): p. 1-12.

30. Abrha, S., et al., Assessment of knowledge, attitude and practice among regular female preparatory school students towards emergency contraceptives in Mekelle, northern Ethiopia. 2014: p. 856-864.

31. Dangat, C.M. and B. Njau, Knowledge, attitudes and practices on family planning services among adolescents in secondary schools in Hai District, northern Tanzania. Tanzania journal of health 
research, 2013. 15(1).

32. Abrha, S., et al., Assessment of knowledge, attitude and practice among regular female preparatory school students towards emergency contraceptives in Mekelle, northern Ethiopia. International Journal of Pharma Sciences and Research 5 (11), 2014: p. 856-864.

33. Fekadu, Y., Knowledge Attitude and Utilization of Emergency Contraception among Health Science and Medical Students of Arba Minch University. J Women's Health Care, 2015. 6(383): p. 21670420.1000383 .

\section{Figures}

\begin{tabular}{|l|l|l|}
\hline $\begin{array}{l}\text { Lost follow up } \\
(\mathrm{n}=10) \text { due to } \\
\text { drop out from } \\
\text { school. }\end{array}$ & $\begin{array}{l}\text { Excluded }(\mathrm{n}=14) \\
\text { Didn't consent } \\
\text { to participate } \\
\text { in the study } \\
\text { (8) }\end{array}$ \\
$\begin{array}{l}\text { Cannot speak } \\
\text { Tigrigna (6) }\end{array}$ \\
\hline Analysed (n=130)
\end{tabular}

\section{Figure 1}

Flow diagram showing subjects initially enrolled, intervened, followed up and included in the analyses in the quasi-experimental study. 


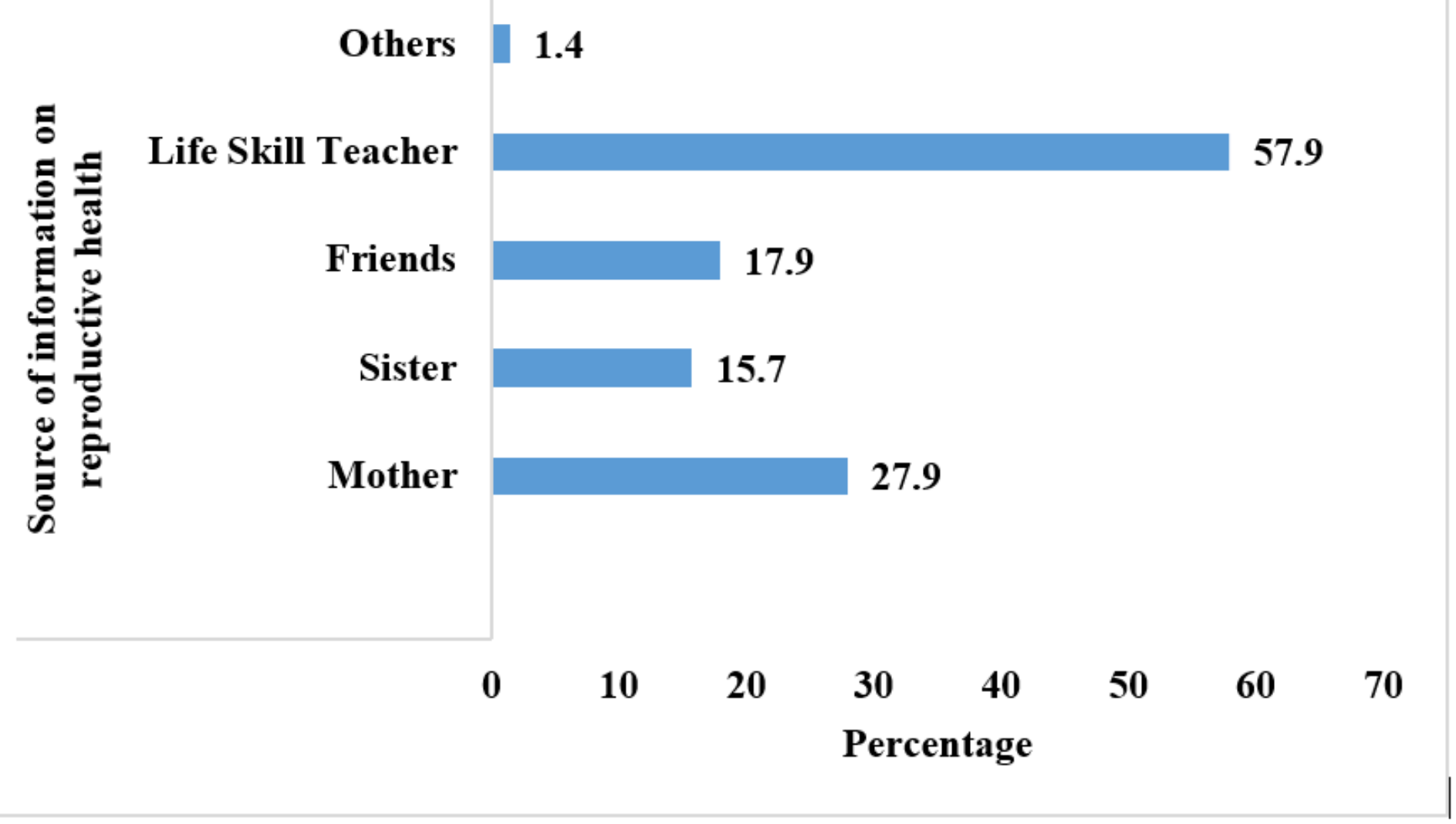

Figure 2

Source of information on reproductive health for the students

\section{Supplementary Files}

This is a list of supplementary files associated with this preprint. Click to download.

- trendchecklist.docx 